\section{References}

Cheng, P. W., \& Novick, L. R. (1990). A probabilistic contrast model of causal induction. Journal of Personality and Social Psychology, 58, 545-567.

Dickinson, A., \& Burke, J. (1996). Within-compound associations mediate the retrospective revaluation of causality judgments. Quarterly Journal of Experimental Psychology: Comparative and Physiological Psychology, 49B, 60-80.

Dickinson, A., Shanks, D. R., \& Evenden, J. L. (1984). Judgement of act-outcome contingency: The role of selective attribution. Quarterly Journal of Experimental Psychology: Human Experimental Psychology, 36A, 29-50.

Kruschke, J. K., \& Blair, N. J. (2000). Blocking and backward blocking involve learned inattention. Psychonomic Bulletin \& Review, 7, 636646.

Le Pelley, M. E. (2002). The interaction of learning and memory in human causal behaviour. Unpublished doctoral thesis, University of Cambridge, Cambridge, England.

Le Pelley, M. E., Cutler, D. L., \& McLaren, I. P. L. (2000). Retrospective effects in human causality judgment. In L. R. Gleitman \& A. K. Joshi (Eds.), Proceedings of the Twenty-Second Annual Conference of the Cognitive Science Society (pp. 782-787). Hillsdale, NJ: Erlbaum.

Le Pelley, M. E., \& McLaren, I. P. L. (2001a). The mechanics of associative change. In J. D. Moore \& K. Stenning (Eds.), Proceedings of the Twenty-Third Annual Conference of the Cognitive Science Society (pp. 534-539). Hillsdale, NJ: Erlbaum.

Le Pelley, M. E., \& McLaren, I. P. L. (2001b). Retrospective revaluation in humans: Learning or memory? Quarterly Journal of Experimental Psychology: Comparative and Physiological Psychology, 54B, 311-352.

Le Pelley, M. E., \& McLaren, I. P. L. (2003). Learned associability and associative change in human causal learning. Quarterly Journal of Experimental Psychology: Comparative and Physiological Psychology, $56 B, 68-79$.
Mackintosh, N. J. (1975). A theory of attention: Variations in the associability of stimuli with reinforcement. Psychological Review, 82, 276298.

Markman, A. B. (1989). LMS rules and the inverse base-rate effect: Comment on Gluck and Bower (1988). Journal of Experimental Psychology: General, 118, 417-421.

Rescorla, R. A. (2000). Associative changes in excitors and inhibitors differ when they are conditioned in compound. Journal of Experimental Psychology: Animal Behavior Processes, 26, 428-438.

Rescorla, R. A., \& Wagner, A. R. (1972). A theory of Pavlovian conditioning: Variations in the effectiveness of reinforcement and nonreinforcement. In A. H. Black \& W. F. Prokasy (Eds.), Classical conditioning: II. Current research and theory (pp. 64-99). New York: AppletonCentury-Crofts.

Shanks, D. R. (1985). Forward and backward blocking in human contingency judgement. Quarterly Journal of Experimental Psychology: Comparative and Physiological Psychology, 37B, 1-21.

Shanks, D. R., \& Dickinson, A. (1987). Associative accounts of causality judgment. Psychology of Learning and Motivation, 21, 229-261.

Suret, M. B., \& McLaren, I. P. L. (2003). Representation and discrimination on an artificial dimension. Quarterly Journal of Experimental Psychology: Comparative and Physiological Psychology, 56B, 30-42.

Van Hamme, L. J., \& Wasserman, E. A. (1994). Cue competition in causality judgments: The role of nonrepresentation of compound stimulus elements. Learning and Motivation, 25, 127-151.

Wagner, A. R. (1981). SOP: A model of automatic memory processing in animal behavior. In N. E. Spear \& R. R. Miller (Eds.), Information processing in animals: Memory mechanisms (pp. 5-47). Hillsdale, NJ: Erlbaum.

Received June 3, 2003

Revision received August 13, 2003

Accepted August 20, 2003

\title{
Correction to Acknowledgment of Ad Hoc Reviewers (2003)
}

The Acknowledgment of Ad Hoc Reviewers (Journal of Experimental Psychology: Animal Behavior Processes, 2003, Vol. 29, No. 4, p. 341) contained three errors.

The names of three reviewers were misspelled. The correct spellings are Brendan McGonigle, Byron Nelson, and Juan M. Rosas. 